\title{
Formation of Environmental Legislation in the Early Years of Soviet Period
}

\author{
Ulukbek Iusupov', Nurlan Altynbaev², Marat Tatenov ${ }^{3}$, Tursunkul Atantaev ${ }^{4}$, Nurbek Arziev5, \\ Nurbek Tabaldiev3 ${ }^{3}$ Avtandil Arabaev6, Gulsara Kuldysheva ${ }^{3}$, Zhypargul Abdullaeva ${ }^{*} \mathbb{C}$
}

${ }^{1}$ Department of Legal Sciences, Modern International University, Jalal-Abad, Kyrgyzstan

${ }^{2}$ Department of Philological Sciences, Modern International University, Jalal-Abad, Kyrgyzstan

${ }^{3}$ Department of Theory and History of Government Law, Osh State University, Osh, Kyrgyzstan

${ }^{4}$ Department of Accounting and Taxes College of Finance and Law, Osh State University, Osh, Kyrgyzstan

${ }^{5}$ Department of Criminal Law Disciplines, Jalal-Abad State University Named after B. Osmonov, Jalal-Abad, Kyrgyzstan

${ }^{6}$ Department of Law, Jalal-Abad State University Named after B. Osmonov, Jalal-Abad, Kyrgyzstan

${ }^{7}$ Science and Research Department, Osh State University, Osh, Kyrgyzstan

Email: *jypar.science@oshsu.kg

How to cite this paper: Iusupov, U., Altynbaev, N., Tatenov, M., Atantaev, T., Arziev, N., Tabaldiev, N., Arabaev, A., Kuldysheva, G., \& Abdullaeva, Z. (2021). Formation of Environmental Legislation in the Early Years of Soviet Period. Open Journal of Social Sciences, 9, 352-358.

https://doi.org/10.4236/jss.2021.97025

Received: June 18, 2021

Accepted: July 20, 2021

Published: July 23, 2021

Copyright $\odot 2021$ by author(s) and Scientific Research Publishing Inc. This work is licensed under the Creative Commons Attribution International License (CC BY 4.0).

http://creativecommons.org/licenses/by/4.0/

\section{(c) (i) Open Access}

\begin{abstract}
This article analyzes formation and development of environmental legislation in the early years of Soviet period based on systemic, comparative-legal, systemic-structural and logical research methods. Political processes of the first half 19th century in the Soviet Union had a huge impact on the part of the public political life of Kyrgyzstan, including the processes of legal development. The main purpose of this article is to study the formation, emergence of the first norms in the field of ecology, their isolation, the formation of codified acts in the first years of Soviet power and identification of especially significant features in the formation of environmental legislation. The research results are useful in the justice, legislative activity, law enforcement practice fields, as well as in scientific research in this area.
\end{abstract}

\section{Keywords}

Declaration, Decree, Legislation, Environmental Legislation, Nature Management, Environmental Relations, Normative Legal Act

\section{Introduction}

After the October Socialist Revolution legal regulation by industry of public relations began the influence on the domestic law development, its forms, system and content (Chernogor \& Pashentsev, 2017). At the same time, however, many 
important social relations were intertwined with politicization (Lantsov, 2017). The Decree of the Council of People's Commissars of the RSFSR on the approval and publication of laws was adopted on October 30, 1917. This Decree provided for draft laws, their consideration by the government and their entry into force and repeal (Russian Federation Constitution, 2021). The Decree of the Central Executive Committee "On Forests" adopted on May 27, 1918 is another important normative legal act about environmental legislation. In our opinion, this Decree established some fundamental provisions for future environmental legislation.

Initially, this act abolished private ownership of forests and recognized them as a common national value. These laws also provide for the centralization of forest management, the powers of the Central Executive Committee, local authorities, i.e. administrative and organizational measures for forestry. It should be noted that it defines the rights and responsibilities of citizens for forest use and regulates some of these rights, in particular, Article 13 of this Decree introduces the norms of forest use, according to which citizens use fuel based on housing, number of stoves or other grounds (Decree on forestry 1917-1928, 1967).

According to Article 29 of the Law on Forest Protection, which is a significant achievement in this legislation, every citizen has the right to appeal to the Soviet authorities. In particular in the following issues:

1) On recognition of forest dachas as protected;

2) On the restriction of forest use;

3) Other measures to protect forest cottages.

We think that this legislation has improved the legal framework for laws adoption, adopted general provisions, regulations and restrictions on the use of natural objects at the legal level. This law recognizes forest fish as a public good and provides citizens with equal rights to use it. Another important piece of legislation in the early years of Soviet power was the Decree of "On Pedigree Animals" on July 19 of 1918 (Alekseeva, 2008), where adopted recommendations for issuing a decree on veterinary supervision for the transportation of cattle by rail and waterways, about the organization supply of veterinary instruments, medicines, disinfectants and on several other issues by the organizing committee. The congress took place on May 7-12, 1919, according to Article 2 of this Decree, all pedigree animals must be included in the Red Book as breeding animals by the zootechnical commission. The most important act of the Central Executive Committee in the field of environmental legislation is the Regulation "On socialist land management and the transition to socialist land management" (Regulations on socialist land management and measures, 1919). According to this provision, all lands in the territory of the RSFSR are included in the single state land fund (RSFSR, 1922).

Following the Article 5 of this regulation, the following responsibilities assigned to land divisions in the following issues: 
1) Separation of agricultural land from other lands;

2) Exclusion of lands from the agricultural fund that cannot be used for personal use;

3) Allocation of agricultural land for public use;

4) Land fund registration.

Research problem in this work is to analyze significant features formation and development of environmental legislation laws in the early years of Soviet period and their influence on the Kyrgyzstan. Research objectives are environmental policy decrees, laws and regulations on the environmental legislation.

\section{Research Methods and Materials}

Research results in this work were obtained based on historical comparative analysis, literature analysis and internet resources review methods. Historical comparative analysis based on information by comparing historical and legal sources; formal logical method gain information based on formal logical methods and techniques exploring the outer law, its sources, typology, classification of legal phenomena and processes (Batyrbaev et al., 2021). Literature analysis of previously published works on environmental legislation and websites.

\section{Results and Discussions}

\subsection{Environmental Legislations in Nature Use}

Formation and development of environmental policy in Soviet Russia were difficult and contradictory, as evidenced by numerous documents, following the V.V. Sokolov, in 1917-1920 years, 268 decrees, resolutions, orders were issued by government bodies on nature management, protection with meaning to a large extent, they were aimed at overcoming the consequences of the predatory use of natural resources in the previous periods (Pugachev, 2008). A significant achievement of this law is the introduction of the allocation of agricultural land from other lands and registration of the land fund. On July 20, 1920, the Council of People's Commissars adopted the Decree "On Hunting" (Historical documents electronic library, 2021a). According to Article 9 of this Decree, the boundaries of hunting were defined, such as reserves, land plots of citizens, reserves, settlements. It also looked at a list of birds and animals whose hunting was prohibited. Therefore, the norms for use of nature have begun to systematize. Therefore, in the first years of the Soviet period, there were significant changes in the field of environmental legislation, which created the basis for the legal regulation of nature use.

It should be noted that the legislation we studied above contains several articles on the use of nature. Examples include the introduction of forest use regulations; citizens have equal rights to use; restricting the hunting of certain birds and animals; separation of agricultural lands from other lands. There is a tendency to be cautious in the use of natural resources. In addition, the legal regulation of nature use relations has improved. 


\subsection{Nature Protection Laws}

The Constitution of the Russian Socialist Federal Republic, adopted on July 10, 1918, occupies a special place in the regulation of environmental relations. The first section of the Constitution was called the Declaration of Exploited Peoples and Workers, and the second section of Article 3 abolished the individual right to land, and all land funds were considered the property of the people (Constitution of the Russian Socialist Federal Republic, 1918). Also, all forests, mineral resources, and water, as well as all living and non-living inventory, are considered the wealth of people. It should be noted that these resources are not only used but also obtained. An example is the Decree of the Council of People's Commissars of September 21, 1918 "On the protection of natural monuments, gardens and parks” (Shamanaev \& Zyryanova, 2018).

According to Article 1 of this Decree, "Natural areas and independent nature (animals, plants, mountains), especially objects considered as scientific, historical and cultural heritage and in need of protection, are recognized as inviolable monuments of nature". One of the most important codified acts in the use of nature is the Land Code of the CRSFR (USSR Legal Acts Library, 2021).

\subsection{Land Code Regulations}

Another important point in the resolution on the entry into force of the Land Code is its paragraph 9, according to which "the issues of land use and land management are closely related to the conditions and procedures for the use of the Forest Fund, so it is proposed to develop and adopt a Forest Code as a continuation of the Land Code" (USSR Legal Acts Library, 2021; Decree all-Russian central executive committee councils of workers, soldiers, peasants and coszak deputies, 1967). This act is the first codified normative legal act in the field of environmental legislation.

The Land Code provides for procedures and institutions for land use, land tenure, their management, distribution, management, as well as disputes over land rights. The sale, gift, and inheritance of any land transactions (Article 27) were prohibited, and these agreements are declared invalid and criminally punishable by confiscation of land. However, in case of predatory treatment of land use and loss of land use, they were temporarily deprived of land (Article 61). As a result, the rational use of natural resources is first enshrined in this article. An important legal act on the legal regulation of natural resources is the resolution of the Central Executive Committee on subsoil and its development.

The resolution recognized mineral resources as the government value and regulates relations in its exploration, management and registration of rights. Another important feature of this resolution is the provision of special permits for the development and exploration of natural resources.

\subsection{Sustainable Economy and Pasture Decrees}

The adoption of the Decree of the Central Executive Committee of the All-Union 
on April 17, 1924 "On the resettlement of the population of the autonomous Kyrgyz Soviet Socialist Republic, transitioning to a nomadic, semi-nomadic and sustainable economy" became one of the first normative acts in national legislation (Sinitsyn, 2018). As an appendix to this Decree, the Regulation "On the resettlement of the population of the Kyrgyz Soviet Socialist Republic, nomadic, semi-nomadic and transition to sustainable farming" was adopted. The adoption of this law is due to the peculiarities of life in Kyrgyzstan.

Paragraph 2 of the Regulation provides distribution of common pastures with nomadic semi-nomadic populations, the allocation of pastures for horses for wintering to nomadic and semi-nomadic populations, the allocation of areas for cultivation and storage of fodder and hay, and consideration of conditions for permanent settlement. In addition, this regulation adopts the rules of land use regulation and establishes a separate norm for cattle breeders engaged in animal husbandry. Kyrgyz pastures are vital for the livelihoods of rural Kyrgyz communities that comprise most of the country's Population (Sabyrbekov, 2019).

Despite the formation of the Kara-Kyrgyz Autonomous oblast, centralized public administration and socially important decisions were made by the Central Executive Committee. However, it should be noted that the powers of local governments have remained formal and accepted. In regulating environmental legal relations, the Central Committee also took into account the specifics of the local population. This Decree, in turn, allowed the local population to independently consider their rights to use nature.

Another serious shortcoming is the lack of consideration of natural objects, their interconnectedness, lack of scientific justification, inconsistency of norms, lack of conciseness. In the early years of the Soviet power, several decrees on the use of nature were adopted. They include the following issues:

1) Decree of the RSFSR "On Hunting" of 1920;

2) Decree of the Council of People's Commissars (CPC) of the RSFSR "On Subsoil" of 1920;

3) Decree of the CPC of the RSFSR "On the protection of monuments of nature, gardens and parks" of 1921;

4) Land Code of the RSFSR of 1922;

5) Forest Code of the RSFSR of 1923 (Historical documents electronic library, 2021b).

Summarizing above, several legislations were adopted including introduction of forest use regulations, equal rights for citizens restricting the hunting of certain birds and animals, separation of agricultural lands from other lands. Several decrees on the protection of natural monuments, gardens and parks; on socialist land management and the transition to socialist land management; on the resettlement of the population of the Kyrgyz Soviet Socialist Republic, nomadic, semi-nomadic and transition to sustainable farming etc.

\section{Conclusion}

With the entry of Kyrgyzstan into a single political arena, important issues in its 
public life have been addressed through a centralized system of government. The results of the analysis of the above legislation show that the formation of environmental legislation in Kyrgyzstan is primarily dominated by legislation on the use of nature, especially the regulation of land, water and forest use.

Research findings are legislations studied above containing several articles on the protection, management and use of nature, land resources in the first years of the Soviet period. Decrees and laws adopted for the land and forest code regulations, sustainable economy and pasture decrees.

\section{Conflicts of Interest}

The authors declare no conflicts of interest regarding the publication of this paper.

\section{References}

Alekseeva, L. V. (2008). The State of Veterinary Medicine during the Revolution and the Civil War. Bulletin of Nizhnevartovsk State University, No. 1, 64-69.

Batyrbaev, B., Aidarbekova, G., Toktombaeva, A., Salybekova, T., Gabieva, T., Kuldysheva, G., \& Abdullaeva, Z. (2021). Legal Policy and Legal Culture in the Kyrgyz Republic System for Public Administration and Judiciary. Open Journal of Social Sciences, 9, 53-61. https://doi.org/10.4236/jss.2021.97005

Decree All-Russian Central executive Committee Councils of Workers, Soldiers, Peasants and Coszak Deputies, May 1918 (1967). About Forests 1917-1928 Years: Collection of Documents for 50 Years (pp. 67-83). Moscow: Politizdat. https://www.booksite.ru/forest/forest/orginize/2.htm

Chernogor, N. N., \& Pashentsev, D. A. (2017). The October Revolution and the Evolution of Russian Law. Journal of Russian Law, 10, 5-13. https://doi.org/10.12737/article 59c4cb55295b01.61454320

Constitution of the Russian Socialist Federal Republic (1918). Adopted by the V All-Russian Congress of Soviets at the Meeting of July 10, 1918.

http://www.hist.msu.ru/ER/Etext/cnst1918.htm

Historical Documents Electronic Library (2021a). Decree of the Council of People's Commissars. About Hunting. July 20, 1920. Collection of Decrees and Decisions on the People's Commissariat of Agriculture. 1917-1920. Moscow: Gosizdat. http://docs.historyrussia.org/ru/nodes/139295-dekret-soveta-narodnyh-komissarov-ob -ohote-20-iyulya-1920-g

Historical Documents Electronic Library (2021b). Decrees of the Soviet government. P. IX. June-July 1920. Moscow: Politizdat. http://docs.historyrussia.org/ru/nodes/11120-20-iyulya-dekret-snk-ob-ohote

Lantsov, S. A. (2017). The October Revolution of 1917: Conceptions and Results. Bulletin of St. Petersburg University. Political Science. International Relations, 10, 289-300. https://doi.org/10.21638/11701/spbu06.2017.401

Pugachev, A. V. (2008). Problematic Aspects of the Formation and Development of Environmental Policy in Modern Russia. Bulletin of Altai State University, No. 4-5, 259-264.

Regulations on Socialist Land Management and Measures (1919). Ttransition to Socialist Agriculture on February 14, 1919. SU of the RSFSR, 1919, No. 4, Art. 43.

Sabyrbekov, R. (2019). Income Diversification Strategies among Pastoralists in Central 
Asia: Findings from Kyrgyzstan. Pastoralism, 9, 14.

https://doi.org/10.1186/s13570-019-0152-x

Shamanaev, A. V., \& Zyryanova, S. Yu. (2018). Security Cultural Heritage in the Russian Empire (132 p.). Tutorial Book. Ekaterinburg: Ural University Publishing House.

Sinitsyn, F. L. (2018). The Pursuit of the Population: Sovietization of the "Nomadic" Regions of the USSR in the 1920s. Petersburg Historical Journal, 4, 126-141.

https://doi.org/10.51255/2311-603X-2018-00077

RSFSR (1922). Land Code of the RSFSR. SU RSFSR, No. 68, 57-410.

Russian Federation Constitution (2021). List of Acts of Constitutional Significance 1600-1918. https://constitution.garant.ru/history/act1600-1918/

USSR Legal Acts Library (2021). Regulations on Socialist Land Management and Measures on the Transition to Socialist Succession from February 14, 1919. The Central Executive Committee of the RSFSR. http://www.libussr.ru/doc ussr/ussr 3712.htm 